\title{
The Sustainability of Health and Safety on Construction Sites in Zamfara State
}

\author{
Ismaila Oladunni Muhammed ${ }^{1 *}$ and Adegbenga Raphael Ashiru ${ }^{1}$ \\ ${ }^{1}$ Department of Building Technology, Federal Polytechnic, KauraNamoda, Zamfara State, Nigeria
}

\begin{abstract}
Construction industry has been attributed to be the growth of Nigerian economic and infrastructural development. Annual reports show that consistent accidents on construction sites in Zamfara State has affected substantial number of workers as they become temporarily or permanently disabled, thereby making many construction sites a death trap. It is as a result of high construction site accident currently experiencing in Zamfara state that this research was carried out to appraise the sustainability of health and safety of construction workers on sites. Subsequently, SPSS Version 20 was used to analyse descriptive statistical analysis. Furthermore, the findings highlighted that the performance and output of construction workers on construction sites depends on proper practice of health and safety. The research findings also recommended ways to enhance employers and employee's compliance to existing laws guiding health and safety on Zamfara State construction sites.
\end{abstract}

Keywords: Construction Industry, Health and Safety Regulations, Causes of Accident, Construction Safety Practices

\section{Introduction}

The Construction industry contributes to nation's economic and social development of Nigeria. To promote real sectoral relations and enhancement, various activities carried out in the sector are very important in maintaining the nation's economic development aside from the industry's potential to generate employment. For example, the significance of provision of accommodation with regards to different types of buildings, industrial development (construction of industrial factories and parks) and infrastructural development (railway, road, sea and air ways), among others cannot be disregarded in attaining a national development and sustainable economy.

Moreover, Construction industry has been pertinent in the economic development of Nigeria where provision of accommodation is a foremost element of the construction sector. As noted by [1], "provision of housing is a crucial contribution in social, economic and civic development. This creates broader socio-economic development goals which were achieved through direct contribution of various housing-related activities. It is a key driver of economic development globally and particularly in developing countries where

\footnotetext{
* Corresponding author: rajisabi20081928@gmail.com
} 
housing construction project generates job prospects". Consistent with the above assertion, [2] observed that economic development through housing matters improves economic performance. Similarly in Nigeria, different categories of employees have secured employment in construction sector, especially in major cities of Nigerian where huge construction activities have been witnessed.

Globally, construction industry is adjudged as a notable hazardous sectors due to huge number of injuries and death record causing a downward trend in the industry attractiveness over the decade due to poor safety practices [3,4]. These accidents dishearten the workforce, escalate project cost, delays project completion, and reduce productivity which in turn drops the reliability rating of the sector. Considerably, this high-rate of accidents and safety anxiety poses great danger to the sustainability of the construction sector itself notwithstanding the fact that many such accidents are either unreported or poor documented. While construction workforce caused most of these construction site accidents (due to poor commitment to work and illiteracy), poor or no safety practises by the construction firms or site employees however may result in many site accidents. In contemporary times, the matter of safety on construction projects has become a thoughtful issue not only to the practitioners, government and general public but academics alike. Therefore, accident prevention can considerably improve performance of workers on project sites where a safe work practice is vital to reduce accidents and realise a reliable workflow in construction processes [5]. It is against this framework that this research was carried out to answer the vital research questions as stated below:

- What is the relationship between causes of accidents and safety challenges faced by workers on Nigerian construction sites?

- How sustainable health and safety practices could be used to control accidents on Nigerian construction sites.

\section{Brief literature review}

The origin of health and safety regulations through research studies had been generally attributed to the UK and US [6,7]. The health and safety regulations contained a frame of laws which, if firmly followed, could meaningfully promote safety and reduce poor construction standards [3].The reason behind the provision of the regulations is to improve safety, welfare of workers and the general public. Though the previous regulations laid more emphasis on the provision of safe working premises [8] and way of avoiding accidents and diseases caused by dangers arising from chemicals and noise [9] but recent developments are channelled towards elimination of hazard which site workers are exposed to. Involvement in decision making by workforce on issues relating to health and safety are also encourage through the new regulations.

Although, many organisations are negligence in complying with these regulations cover different facets of construction activities. Before and even after independence, Nigeria exclusively depended on British standards and regulations. As a result, most of health and safety regulations used as reference in Nigeria are coined out from foreign countries health and safety regulations except famous Factory Act [10].

Furthermore, [11] revealed a study which shows that older experienced workers have lesser injuries than young and less experienced workers. According to the Australian Bureau of Statistics in 2001, the age group 0-15 and 16-24 experienced greater fatalities. They maintained that younger age group of workers experienced higher cases of accidents. Also, [12] research showed that older workers work safer than workers that are lesser 25 years. He further attributed that young employees can easily be influenced by employers to involved in unsafe tasks since they rarely know their rights. Young workers may contribute 
greater risk on construction sites[13] thus adequate supervision and training is vital when engaging the services of young workers.

According to [14], construction sites accidents are unquantifiable and inevitable, whether fatal or minor could amount to loss of resources. To justify the aforesaid, [15] argued that direct and indirect impacts result from construction site accidents. Construction sites injuries may have direct impacts on the productivity level as well as individual involved. Moreover, indirect impact could be income losses on client side due to late delivery. Many Employers as argued by [16], fail to established complete policies on accident prevention, rather they concentrate on profit maximisation. They placed low emphasis on safety issues owing to gross ignorance of the comparative cost advantage of accident prevention over accident treatment. This is in consonance with [14] who maintained that greater interest has been placed on cost, quality and schedules compared with attention to safety of the workers who are the originator of construction work. Again, [16] strongly agreed with [14] who further revealed that upsurge exposure of workforce and the general public to construction site risk have been attributed to poor devotion towards safety causing high unintended occurrence of accident. According to [17], accidents does not only result injury to the workforce, but also cause great damage to materials tools and equipment. Therefore, future projects accident forecast would be of great benefit for budget preparation and allocation to reduce the optimal damages [18]

\subsection{Causes of accident on nigeria's construction sites}

There are many causes of construction project site accident. Ways of curbing or reducing construction project site accident is solely the responsibility of site manager or supervisor. Scholars revealed that acts of God or disasters are events which cause severe harms to construction stakeholders, product and process [19]. Landslides, rain, flooding, earthquake, wind are numerous acts of God that causes fatalities on sites. [20] pointed out that workers had higher chance to slide off from scaffold and fall from height when carrying out construction site works during the raining season than during the dry season.

Since construction workforce generally works on unsheltered environment, continuous contact with adverse weather generally leads to their illness [21]. Continuous contact to noise from welding, explosives on site, noise emanated from heavy equipment are key sources of occupational deafness [22]. An unwelcome human action or decision that has the possibilities for reducing the effectiveness of safety performance on construction site is measured through human error as advocated by [23]. This can further be credited to failures on the part of construction workforce, poor concentration at work, errors in judgements, poor cognisance on construction site hazard and safety requirements.

A research conducted in turkey categorised causes of construction accidents into poor attention, unsafe behaviour, ignoring safety rules, abusing working at height rules, disusing of hand tools and lifting equipment's, poor of control of equipment and maintenance, lack of experts and technical staff, lack of training and inspection [24]. More so, [25] fixed world annual number of fatal constructions sites accidents at around 60,000. Furthermore, there are various types of accidents with varying rates of fatalities and occurrence from preceding works to scaffold accidents [26, 27, 28, 29]; slip, trips and falls accidents [30], crane accidents [31,32], crush of ladder [26], electrical and electrocution accidents [33].

Lastly, Zamfara State construction sector does not have records of construction related accidents where more than $80 \%$ of the construction workers are locals working without formal training. Therefore, formal safety training is required for all construction site workers and personnel have to increase their awareness level about safety and control accidents. 


\section{Methodology}

The objective of this study was realised by using two key approaches (through literature review and field survey). The literature review was used to summarise the types and causes of construction sites accidents while the field survey involving 28 construction sites in Zamfara State were used to explore factors that causes accidents, the types of accidents been encountered onsite, the frequency of health and safety measures and builders and nonbuilders perspectives on factors that causes construction site accidents. Nevertheless, a nonprobability sampling was adopted as this enables us to select participants based on the research area in the selected construction sites. This assumed a purposive sampling strategy where participant were selected at the discretion of the researcher but with the sole purpose to be typical of the whole population and the research questions were best examined to evaluate participant engagement. The sample size covered experts such as the site supervisor, site engineer, site architect, general foreman and site quantity surveyor of the contracting firm totalling 140 participants who were assigned code names to maintain confidentiality.

A total number of 140 well-structured questionnaires were distributed to construction professionals on 28 selected projects. 130 questionnaires (representing 93\%) were duly completed and returned. The data collected was analysed by descriptive analysis and inference statistics. The research instrument also measures a reliability and validity test of 0.744. Furthermore, data relating to causes of accidents was extracted by five question items each for achievement and participative construction operatives. These questions where adopted from [20, 22, 23, 24, and 25] to develop principal causes of construction site accidents for the research work. Similarly, five questions adopted from [26, 27, 28, 29, 30, 31,32 and 33] to develop questions for types of construction site accidents. Lastly, Levene test was used to ascertain the equality of variance for the research work.

\subsection{Findings and analysis}

Table 1. Descriptive Statistics of Questionnaire Administered

\begin{tabular}{|l|l|l|}
\hline & Mean & Std. Deviation \\
\hline Profession & 2.38 & 1.235 \\
Age & 2.08 & 0.796 \\
Gender & 1.04 & 0.196 \\
Experience & 3.58 & 0.643 \\
Encounter & 2.88 & 1.177 \\
Faulty Equipment & 2.00 & 1.020 \\
Excessive Noise & 1.85 & .881 \\
Poor Use of Personal protective & 2.73 & 1.402 \\
equipment's & 3.23 & 1.505 \\
Human Error & 3.31 & 1.436 \\
Poor Safety Training & 1.92 & 1.230 \\
Collapse of building & 2.38 & 1.359 \\
Collapse of Scaffold & 2.77 & 1.366 \\
Fall from Height & 2.77 & 1.275 \\
Slip and Trip & 3.38 & 1.525 \\
Stepping on Sharp object & 2.88 & 1.479 \\
Site Safety measures & &
\end{tabular}




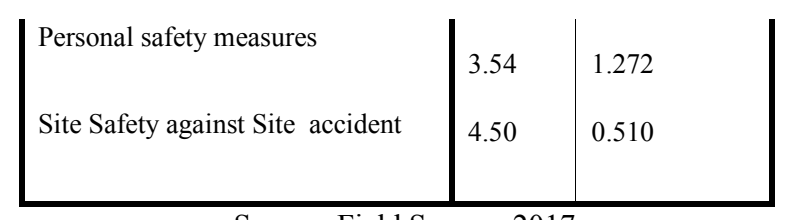

Source: Field Survey, 2017

The table 1.1 above shows descriptive statistics of questionnaire administered to the respondents, it further showed the mean of the frequency and the mean determined the rating of each question.

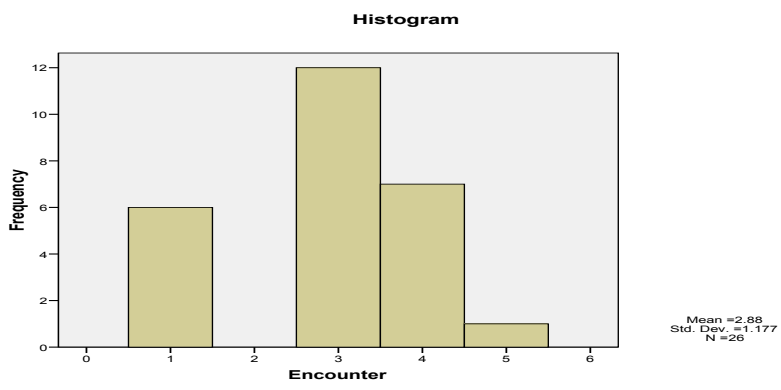

Fig. 1. Respondent Encounter with Construction Related Accidents Source: [Field Survey, 2017]

From table 1, the field survey analysis of mean 2.88 was obtained. There were moderate number of the respondents have encounter construction related accidents before. This implies that construction related accidents in Zamfara State are at its moderate level and can still be easily control.

Table 2. Descriptive Statistics of the Principal causes of Construction site accident in Zamfara State

\begin{tabular}{|l|l|l|}
\hline Principal Causes & Mean & Std. Deviation \\
\hline Poor Safety Training & 3.31 & 1.436 \\
Human Error & 3.23 & 1.505 \\
Poor Use of Personal Protective & 2.73 & 1.402 \\
Equipment & 2.00 & 1.020 \\
Faulty Equipment & 1.85 & 0.881 \\
Excessive Noise & & \\
\hline
\end{tabular}

Source: Field Survey, 2017

The empirical evidence shows from table 2 that the principal causes of construction site accident in Zamfara State as revealed by the respondents were attributed to poor safety training of the workers with mean value of 3.31 while excessive noise is the least cause (mean value of 1.85). This is further strengthened by the research study carried out by [16] that construction firms fails to established complete policies on accident prevention, rather, they concentrate on profit maximisation. They further maintained that construction firms placed low emphasis on safety issues because they are not aware of high cost of accident treatment. More so, the empirical analysis further agreed with [23] who advocated that an 
unwelcome human action or decision that has the possibilities for decreasing the effectiveness of safety performance on construction site is human error. However, the empirical analysis further agreed with [21] on excessive noise caused by welding and heavy equipment's on construction site but maintained that excessive noise is at its very low stage in causing construction site accidents in Zamfara State.

Table 3. Descriptive Statistics of the Principal types of Construction Site Accidents

\begin{tabular}{|l|l|l|}
\hline $\begin{array}{l}\text { Types of Construction Site } \\
\text { Accidents }\end{array}$ & Mean & Std. Deviation \\
\hline Stepping on Sharp Objects & 3.38 & 1.525 \\
Slip and Trip & 2.77 & 1.275 \\
Fall from Height & 2.77 & 1.366 \\
Collapse of Scaffold & 2.38 & 1.359 \\
Collapse of building & 1.92 & 1.230 \\
& & \\
\hline
\end{tabular}

Source: Field Survey, 2017

Also, empirical evidence from table 3 of the research shows that the principal types of construction site accidents commonly experienced in Zamfara State is attributed to stepping on sharp objects while collapse of building is the list types of accidents. Although, many researchers have not laid more emphasis on stepping on sharp objects as one of the principal type of construction site accident but this is the case in Zamfara State. Moreover, the implication of this type of construction site accidents in Zamfara State as the respondents had pointed out is that many of the workforce on site are liable of getting injured through this means and it may be due to untidiness of construction sites and unsafe behaviour of most of the construction site workers.

Table 4. The Result of Independent Sample t Test for Builders and non-Builders perceptions on the Principal Causes of Construction Site accidents

\begin{tabular}{|c|l|l|l|l|l|}
\hline Variables & $\mathrm{M}$ & $\mathrm{SD}$ & $\mathrm{T}$ & $\mathrm{df}$ & $\mathrm{p}$-value \\
\hline Faulty Equipment & & & & & \\
\hline$\bullet \quad$ Builders & 1.70 & 0.73 & -3.21 & 24 & $0.004^{*}$ \\
\hline $\begin{array}{l}\text { Non } \\
\text { Builders }\end{array}$ & 3.00 & 1.27 & & & \\
\hline Excessive Noise & & & & & \\
\hline$\bullet \quad$ Builders & 1.60 & 0.60 & -2.083 & 5.75 & 0.084 \\
\hline $\begin{array}{l}\text { Non } \\
\text { Builders }\end{array}$ & 2.67 & 1.21 & & 1 & \\
\hline $\begin{array}{c}\text { Poor Personal } \\
\text { Protective } \\
\text { Equipment }\end{array}$ & & & & & \\
\hline$\bullet \quad$ Builders & 2.82 & 1.50 & 0.96 & 12.0 & 0.356 \\
\hline $\begin{array}{c}\text { Non } \\
\text { Builders }\end{array}$ & 2.33 & 1.03 & & & \\
\hline Human Error & & & & & \\
\hline$\bullet \quad$ Builders & 3.15 & 1.57 & -0.492 & 24 & 0.627 \\
\hline $\begin{array}{l}\text { Non } \\
\text { Builders }\end{array}$ & 3.50 & 1.38 & & & \\
\hline Poor Safety Training & & & & & \\
\hline$\bullet \quad$ Builders & 3.30 & 1.53 & -0.049 & 24 & 0.961 \\
\hline
\end{tabular}




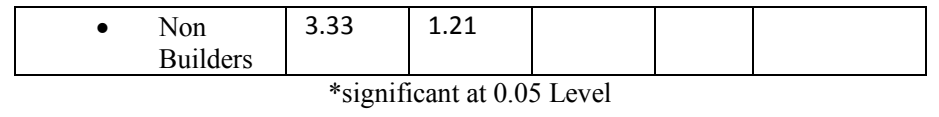

From table 4, At 0.05 p-value, Both Builders and non-Builder appear not to differ in their perception on the principal causes of Construction site accident such as excessive noise $(\mathrm{t}=$ -3.207, $\mathrm{df}=24)$, poor use of personal protection equipment $(\mathrm{t}=-2.083$, df 5.751), Human error $(\mathrm{t}=0.96, \mathrm{df}=12.027)$ and Poor Safety Training $(\mathrm{t}=-0.492, \mathrm{df}=24)$ except for faulty equipment $(\mathrm{t}=-0.049, \mathrm{df}=24)$ where non Builders hold stronger perception than Builders. The implication of this is that non-Builders agree more than Builders that faulty or defective equipment or tools as the principal cause of construction site accidents.

Table 5. The Result of Spearman's rho Correlations between Five principal causes of construction site accidents and five types of Construction site accidents

\begin{tabular}{|l|c|c|c|c|c|}
\hline & $\begin{array}{c}\text { Faulty } \\
\text { Equipment's }\end{array}$ & $\begin{array}{c}\text { Excessive } \\
\text { Noise }\end{array}$ & $\begin{array}{c}\text { Poor } \\
\text { Personal } \\
\text { Protective } \\
\text { Equipment }\end{array}$ & $\begin{array}{c}\text { Human } \\
\text { Error }\end{array}$ & $\begin{array}{c}\text { Poor } \\
\text { Safety } \\
\text { Training }\end{array}$ \\
\hline Collapse of building & & & & & \\
\hline Correlation & 0.007 & 0.279 & 0.042 & -0.099 & -0.103 \\
\hline Sig $(p<0.05)$ & 0.974 & 0.167 & 0.838 & 0.631 & 0.618 \\
\hline Collapse of Scaffold & & & & & \\
\hline Correlation & -0.068 & -0.138 & 0.084 & 0.016 & 0.286 \\
\hline Sig $(p<0.05)$ & 0.742 & 0.500 & 0.682 & 0.938 & 0.157 \\
\hline Falls from Height & & & & & \\
\hline Correlation & 0.062 & 0.005 & 0.143 & $\left.0.3900^{*}\right)$ & 0.271 \\
\hline Sig $(p<0.05)$ & 0.762 & 0.982 & 0.485 & 0.049 & 0.181 \\
\hline Slip \& Fall & & & & & \\
\hline Correlation & -0.310 & 0.024 & 0.331 & -0.121 & 0.030 \\
\hline Sig $(p<0.05)$ & 0.123 & 0.906 & 0.099 & 0.556 & 0.885 \\
\hline Stepping on Sharp & & & & & \\
\hline Objects & -0.115 & 0.063 & 0.114 & 0.183 & 0.235 \\
\hline Correlation & 0.575 & 0.759 & 0.581 & 0.371 & 0.249 \\
\hline Sig $(p<0.05)$ & $*$ Correlation significant at 0.05 Level $(2$ tailed $)$ & & \\
\hline
\end{tabular}

At 0.05 level of p-value, the findings shows from table 5 that there is a strong positive correlation between human error and fall from height (correlation $=0.390$ and $\mathrm{p}$-value $=$ 0.049 ) where the correlation significant is lesser than 0.05 was in-turn found to have greater influence on site productivity. The implication of this correlation is that the more a site supervisor or manager can reduce human error to the barest minimum, the lesser a fall from height will occur. Arguably, fall from height has greater possibility of occurring when human error is left unattended to.

\section{Conclusion}

The research conducted in Zamfara State construction sites revealed that there was high poor safety training of the workers which attributed to high increase in construction site accidents. This result is further strengthened by the research carried out by [16] which stated that construction firms failed to established complete policies on accident prevention, rather, they concentrated on profit maximisation. More so, the empirical analysis further agreed with [23] who advocated that human error had the possibilities for decreasing the effectiveness of safety performance on construction site. Furthermore, the $t$ test shows that there is a strong correlation between human error and fall from height and with greater 
significant on site productivity. Therefore, human error needs to be avoided through personal safety measured which can be achieved by proper orientation and training of construction workers on health and safety regulations and its compliance by the construction firm.

\subsection{Recommendation}

- It is recommended that the construction industries must comply with site safety training for their workers.

- The site surrounding should always be tidy-up. Construction workers should always wear their personal protective equipment.

- Human error should be completely eradicated on site by training the workers on safety awareness.

\section{References}

1. S. Dantata . General overview of Nigerian construction industry, (2008).

2. D. Dawaki. Project Execution Through Direct labor In: Achieving an effective construction industry in Nigeria. Proceedings of a seminar held at Bayero University, Kano Nigeria.12-21, (1987).

3. R. Donaghy. One Death is Too Many: Inquiry into the Underlying Causes of Construction Fatal Accidents. [Online]. [cited on 15 May 2017 http://www.dwp.gov.uk/docs/one-death-is-too-many.pdf (2009)

4. HSE. Health and Safety Executive Statistics 2009/2010 [online]. [cited on 17 April 2017] http://www.hse.gov.uk/statistics/overall/hssh0910.pdf (2011)

5. T.M Toole. Construction Site Safety Roles. Journal of Construction Engineering and Management, 128(3), pp. 203-210, (2002)

6. I. Gilbraith. Occupational safety on construction sites in Malaysia, An Appraisal study of statutory requirements and Awareness, (1989).

7. E. Fellows, A. Duff and M. Well. Safety measures and occupational hazards In indigenous construction firms. International Journal of Project Management, 20(5): 26-40, (2004).

8. H.C. Lingard, T. Cooke and N. Blismas. Group-level Safety Climate in the Australian Construction Industry: Within-group Homogeneity and BetweenGroup Differences in Road Construction and Maintenance, Construction Management and Economics, 27(4), pp. 419-432, (2009).

9. A. Wolf and A. W Brick. Health and Safety on Construction Sites: A Comparison the UK and Germany. Construction Paper 63, Chartered Institute of Building, (1996).

10. G.I Idoro. Provision of PPE and its relationship with health and safety Performance of Nigerian construction contractors. The Professional Builder, Journal of the Nigerian Institute of Building, pp: 3-14, (2007).

11. L.T Bruno and N.A Anigbogu. The use of personal protective equipment's (PPE) on construction sites in Nigeria, (2012).

12. P. McEvoy. Safety performance in twenty construction sites in Dublin. MPhil thesis. Dublin Institute of Technology, (2007).

13. Y. Wang. A study of construction site accidents statistics. Department of civil engineering, south China University Guangzhou, P.R China, (1998).

14. O.J Oladiran, O.E Ogunsanmi and A.A Soyingbe. Control Measures of Accidents: Nigerian Building Projects' Case: Proceedings of CIB - 2008 - Transformation through Construction, 15th - 17th November, Dubai. pp. 1-2, (2008). 
15. N.N Auguster, H.H Mimi and K. Kamariza. Relationship between Unsafe Acts/Condition and Accidents in Construction Company in Nigeria. Journal $\begin{array}{llllll}\text { Teknologi } \quad \text { (Sciences } \quad \& \quad \text { Engineering) } & \mathbf{7 5}: 6 \quad \text { (2015) }\end{array}$ www.jurnalteknologi.utm.my.elssn2180-3722 pp. 74. (2015).

16. R.A.H Abdul and Z.A.M Muhd. Causes of Accidents at Construction Sites. Malaysian Journal of Civil Engineering 20(2): 242-259 (2008).

17. A.S Ali, S.N Kamaruzzaman and G.C Sing. A Study on Causes of Accident and Prevention in Malaysian Construction Industry. Journal Design and Built, ISSN: 1985-6881. 3. pp. 95, 103, (2010).

18. W.A. Asanka and M. Ranasinghe. Study on the Impact of Accidents on Construction Project. 6th International Conference on Structural Engineering and Construction Management 2015, Kandy, Sri Lanka, 11th - 13th December 2015

19. Y. Fatih. Monitoring and Analysis of Construction Site Accidents by Using Accident Analysis Management System in Turkey. Journal of Sustainable Development, 8 (2), ISSN 1913-9063 E-ISSN, 1913-9071. Published by Canadian Centre of Science and Education. pp. 63-64, (2015).

20. N.U Siriwardena. Disaster in search of definition: Specific Construction Industry. Journal of research institute for the built environment. University of Salford U.K pp249-257, (2006).

21. O.O Sotoire. A comparative study of safety measures in indigenous and Multinational construction Firms in Nigeria. M.Sc thesis, department of Building, University of Lagos, Nigeria, (1992).

22. A.A Adeniye. Health and Safety on Construction Site. Journal of Nigeria Institute of Building, (2001).

23. J.S Lucy, J. Ian, and V. Ian. Increasing construction productivity through total loss Control; Journal of R.I.C.S research foundation COBRA, pp. 266-276, (1999).

24. Z.O Kadiri, T. Nden, G.K. Avre, T.O. Oladipo, A. Edom, P.O Samuel, and G.N Ananso. Causes and Effects of Accidents on Construction Sites (A Case Study of Some Selected Construction Firms in Abuja, FCT Nigeria) IOSR Journal of Mechanical and Civil Engineering (IOSR-JMCE), e-ISSN: 2278-1684, P-ISSN: 2320-334x, 5 (1) P. 66-72, (2014).

25. O.S.H.A Construction Industry Digests: occupational safety and health administration (revised Edition) U.S department of labour, (2002).

26. HSE. An Analysis of the Significant Causes of Fatal and Major Injuries in Construction in Scotland. Research Paper 443. London: Health and Safety Executive, (2006).

27. M. McCann. and D. Paine. when is a fall not a fall? Power through partnerships: 12 th annual Construction safety and health conference, proceedings. pp; 21-23, (2002).

28. United States Department of Labour. Accidents in construction industry of Hong Kong (2000-2004) accident analysis and information division labour department, (2005).

29. T. Tappin. Slip, Trip And Falls In Residential Construction. Journal of center for human factors and Ergonomics, 5(4), ISSN 1174-1234, (2004).

30. R.L Neitzel, N.S. Seixas and K.K. Ren. A Review Of Crane Safety In The Construction Industry. Applied occupational and environmental hygiene, pp.16, (2001).

31. O.O Skinner. Tower crane stability CIRIA C654 (2006)

32. A. J. Taylor. Fatal Occupational Electrocutions In the United States. A Journal of Occupational Medicine 52: 102 -106, (2002) 
33. J.C. Crowley and G.T. Homce. Occupational Electrical Injuries In The United States (1992-1998) And recommendations for safety research: Journal of National Institute For Occupational Safety and Health U.S.A, (2001) 